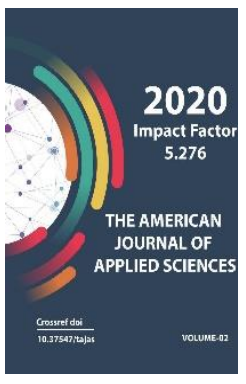

Copyright: Original content from this work may be used under the terms of the creative commons attributes 4.0 licence.

\section{Analysis Of Constructions And Building Materials Of Architectural Monuments Of Khiva}

\section{Durdieva G.}

Khorezm Mamun Academy, regional branch of Academy of Sciences of the Republic of Uzbekistan, Markaz-1, Khiva city, Republic of Uzbekistan

\section{Zargarov A.}

Khorezm Mamun Academy, regional branch of Academy of Sciences of the Republic of Uzbekistan, Markaz-1, Khiva city, Republic of Uzbekistan

\section{Salaev E.}

Khorezm Mamun Academy, regional branch of Academy of Sciences of the Republic of Uzbekistan, Markaz-1, Khiva city, Republic of Uzbekistan

\section{Saburov K.}

Khorezm Mamun Academy, regional branch of Academy of Sciences of the Republic of Uzbekistan, Markaz-1, Khiva city, Republic of Uzbekistan

\section{Khudayberganov B.}

Khorezm Mamun Academy, regional branch of Academy of Sciences of the Republic of Uzbekistan, Markaz-1, Khiva city, Republic of Uzbekistan

\section{Rustamov I.}

Khorezm Mamun Academy, regional branch of Academy of Sciences of the Republic of Uzbekistan, Markaz-1, Khiva city, Republic of Uzbekistan

\title{
ABSTRACT
}

In this article, the methods of construction of minarets of Khiva, architectural composition, building materials, history of construction, devices of aboveground and underground parts, which are of special importance in the ancient Khorezm architecture, are described in scientific sequence and indepth analysis for the first time. Much of this information is being inserted into scientific circulation for the first time.

\section{KEYWORDS}

Architectural monument, minaret, basement, lantern, construction material, spiral, mezzanine, lantern, staircase, earthquake resistant. 
The American Journal of Applied Sciences

(ISSN - 2689-0992)

Published: December 31, 2020 | Pages: 160-169

Doi: https://doi.org/10.37547/tajas/Volume02Issue12-25

\section{INTRODUCTION}

Most of the cities in the ancient Khorezm oasis were built long before us, and their architect was well versed in mathematics, geodesy, astronomy, and algebra, as well as in urban planning, architecture, and painting. One of the main tasks of each of us is to testify that the architecture and construction of the ancient cities of the world, such as Rome, Egypt, and Mesopotamia, and show the progress of architecture and construction. There is no exaggeration.

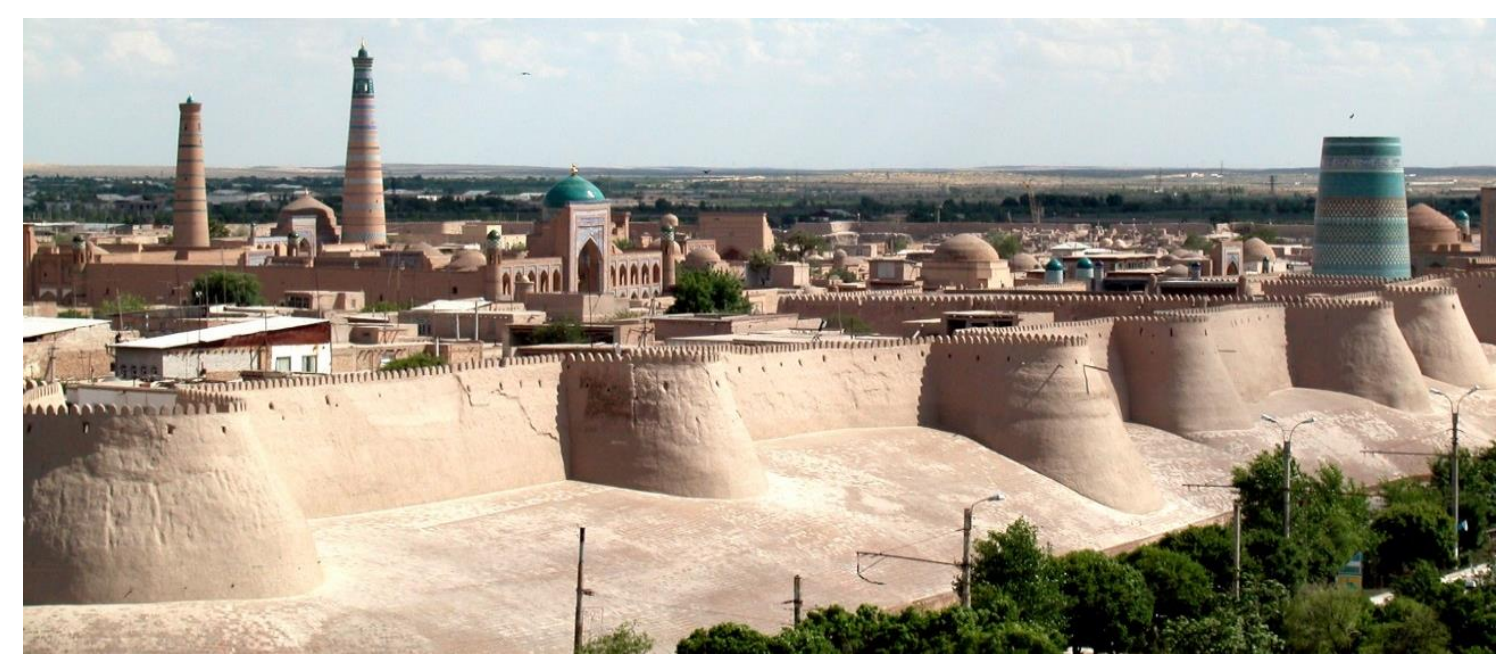

Figure 1. Ichan Castle Slope wall and slope

The smallest building piece of building materials is the elements of architectural monument structures. We need to look in detail to describe their design elements. The best way to look at the architectural monuments is to look at their technical condition. The network method of splitting one or another part of the building is considered.

The interaction between different elements in the construction of an architectural monument, such as a brick-mix or a change in the environment around a dome-wall, depends on how its branches are transferred to each other and their interaction. The masters skillfully used local raw materials in the restoration of architectural monuments, changing the conditions of the place, the differences between the external and internal air of the room, that is, the most responsive to the effects of moisture and heat. The size of the elements that formed them played an important role in the restoration of ancient Khorezm architectural monuments. A special feature of the perfect functioning of the construction of monuments is the interrelationship of the following factors

- Bricks, sandstones, boulders, piles and other elements of similar form;

- Functionally interconnected parts such as walls, columns, domes, foundations (the functional part represents the whole thing);

The whole functional side, that is, the facade sides of the building. The results of the study of the interaction of environmental expressions 
with these functional groups within a single group determine how stable and unstable the "monumental-environment" is. For a better quality of brick, additional compacting materials such as crushed straw, fine gravel and sand are added. In ancient Khorezm, one of the oldest earthquake-proofing activities was the characteristic feature of constructing buildings with sand.

\section{MATERIALS AND METHODS}

Ancient Khorezm, one of the most important elements of antique defense in the early

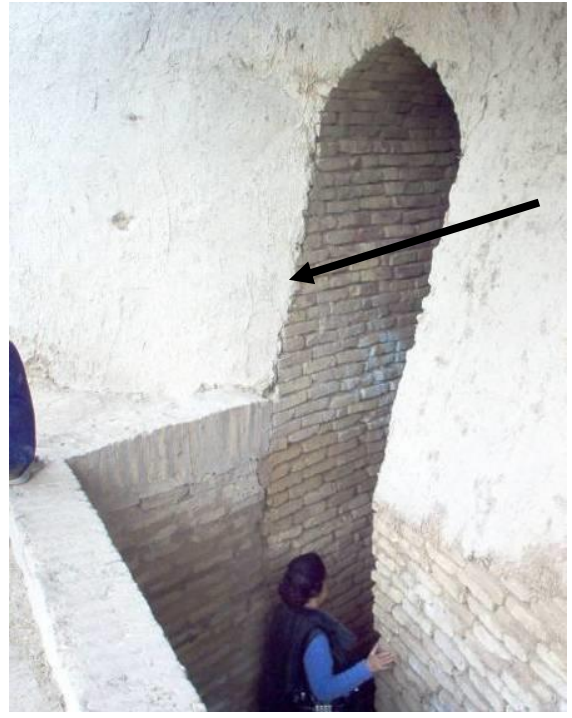

a) construction, was built on a common platform - a common platform - exterior and interior wall, without foundation. To rebuild the platform, the rectangular area was originally surrounded by a thick brick wall, then filled with sand and raw brick. Pahlavi fortresses were thick, and rooms were built between them to make it more efficient.

There are also rooms inside the Ichan-Qala pavement wall, which show the architectural composition of the pavement wall as shown in Figure 1. Occasionally, poles are placed behind the walls to increase wall strength (Figure 1, b).

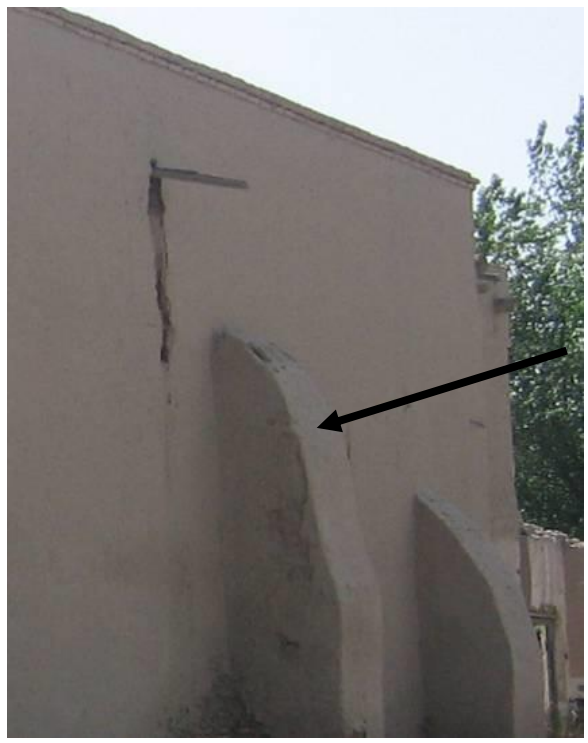

b)

Figure 1. The entrance of the room in the middle of the pile of Ichan-Qala (a; "Counterfeit" for enhancing wall strength (b)

The fortress walls and the upper part of the zodiac were narrower, while the basement was much wider, meaning the wall was significantly sloping, resulting in a smaller platform area than the lower one (Figure 1).

As can be seen from Figure 1, there are 45 ovalshaped burjs around the perimeter of the paxsa wall, which also play an important role in securing the walls.

From the 10th century until the 20th century, burnt bricks were used extensively in the construction of buildings in Khiva. The increase in brick materials had a major impact on the development and improvement of luxury buildings. 
Chorsu-square bricks used in the construction of architectural structures of Khiva- from $21 \mathrm{~cm}$ to $28 \mathrm{~cm}$, and from 2.5 to $8 \mathrm{~cm}$ thick. The change in the thickness of the brick influenced the change in the consumption of the bricks at the time of picking. The thinner the brick, the more expensive the mixture used to collect. For example, in the Garden Gate in Khiva, the mix was spent on picking a small piece of the $\operatorname{rod}(21 \times 21 \times 2.5 \mathrm{~cm})$ in the form of chorsu.
Figure 4 below shows the bricks used in the architectural monuments of Khiva, which are very rare, that is, differing in size from the other bricks. In the course of the reconstruction of "Dehkan Bazar" in the territory of Deshan Qala in June 2011, we could relocate the underground trench or the drainage system, which is still unknown, as we attend the relocation of the "Yugurak Bobo" mausoleum. We found the remains of very strong and unique bricks (Figure 3).

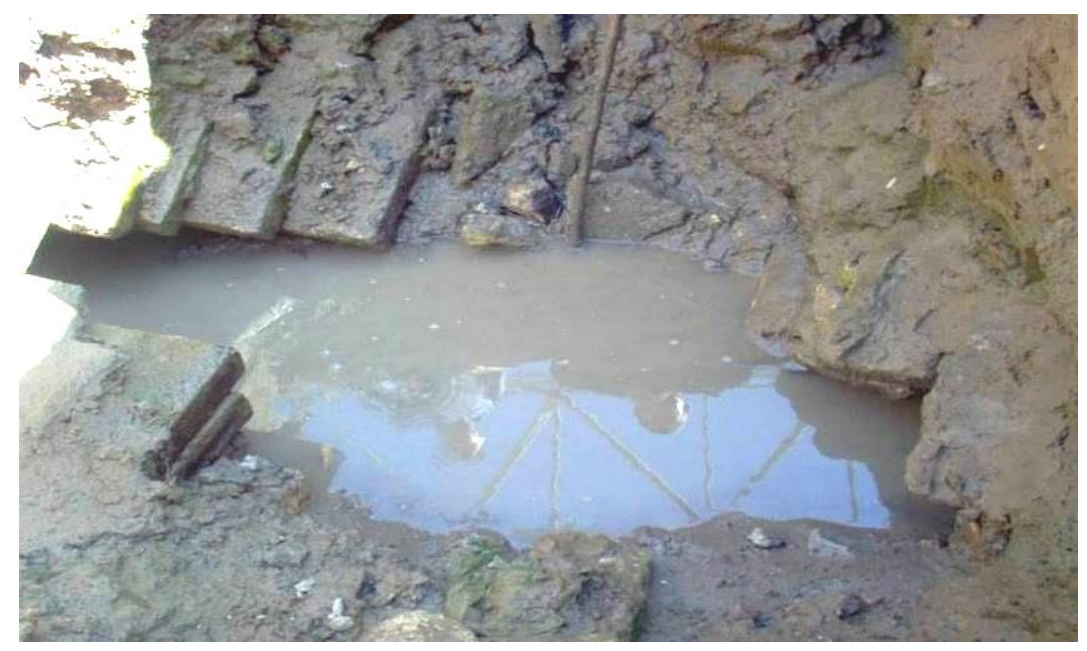

Figure 3. An underground passage found in the Deshan Qala, or any construction waste related to the drainage system

Unfortunately, at the time of the survey, the underground corridor was full of water, we removed the water in special pipes and stamped on the surface $-26.0 \times 12,2 \times 7,0 \mathrm{~cm}$; We took samples of bricks of $26.0 \times 26,0 \times 7,0 \mathrm{~cm}$ (Figure 4). 

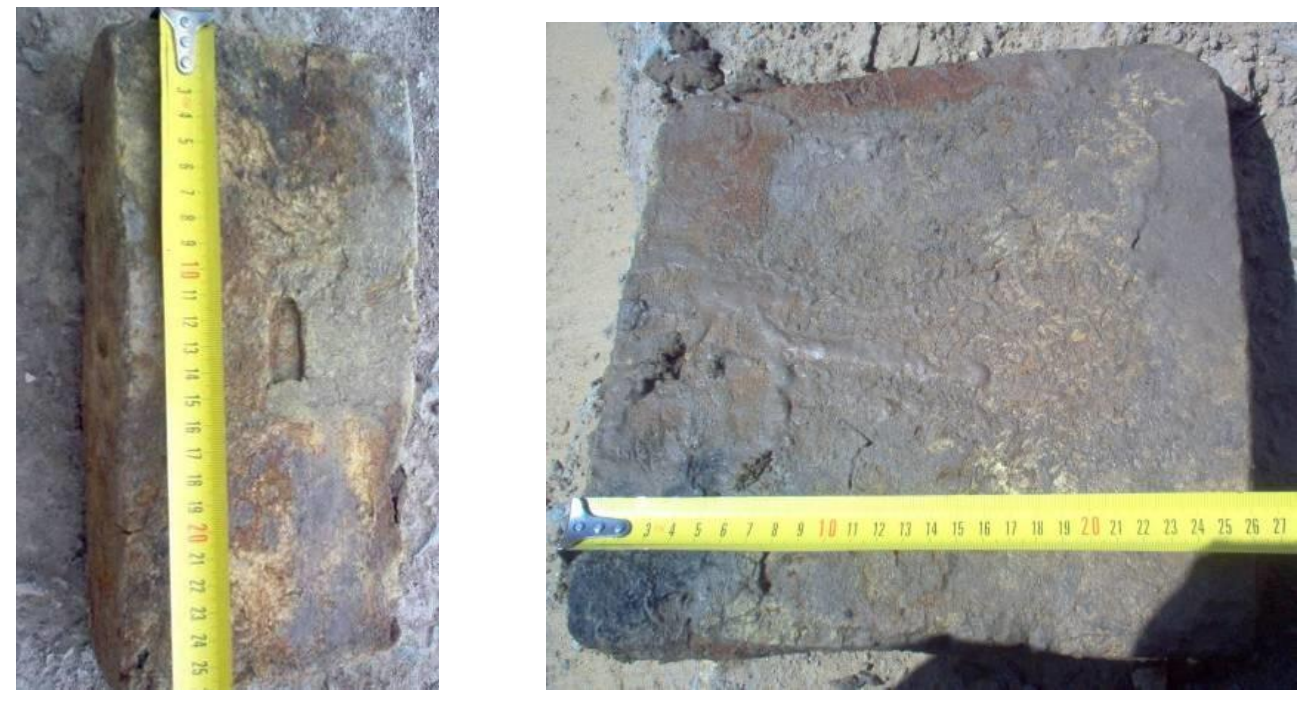

Figure 4. View of unique bricks of various sizes, obtained from underground drainage system found in Deshan Qala)

The architects of the time paid great attention to the quality of the bricks used in the construction to enhance the resistance of the wall structures to their environmental impact and their carrying capacity, that is, every single brick that was examined was checked, broken, well cooked and the same color.

It is not accidental that the brick's torso is in shape, and if it is affected from above, an equal distribution of forces on the surface is achieved, that is, the brick worked equally well on the " $\mathrm{X}$ " and " $\mathrm{U}$ " axes. The brick-and-mortar designs, adhered to by the surface of the bricks, worked well for earthquake effects.
As the architectural monument reaches the top, the foundation, the wall, the vertical wall, and the roof, over it, are dominated by interconnected structures of the domes. The floor and foundations constitute the main network design to ensure the sustainability of architectural monuments. Most of the architectural monuments in Khiva are covered with boulders and the upper part is made of durable bricks. At the 45-degree angle of the foundation brickwork, the brickwork was also

"arched" (Figure 5), which increased the earthquake-proof nature of the structure. 


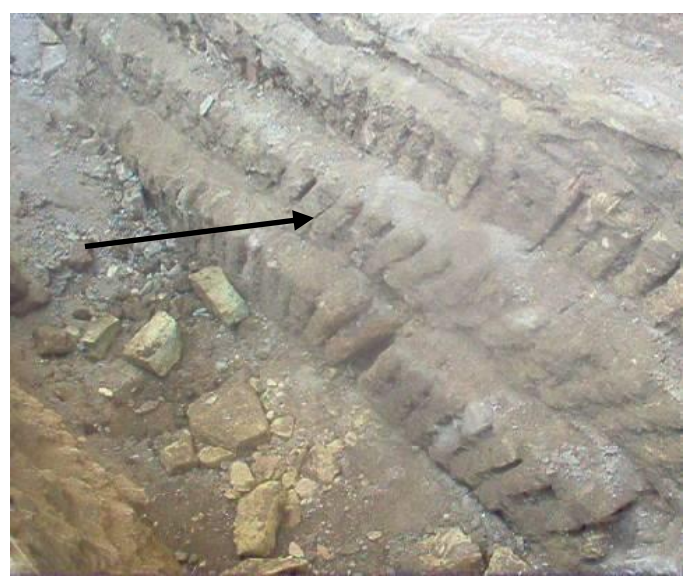

a)

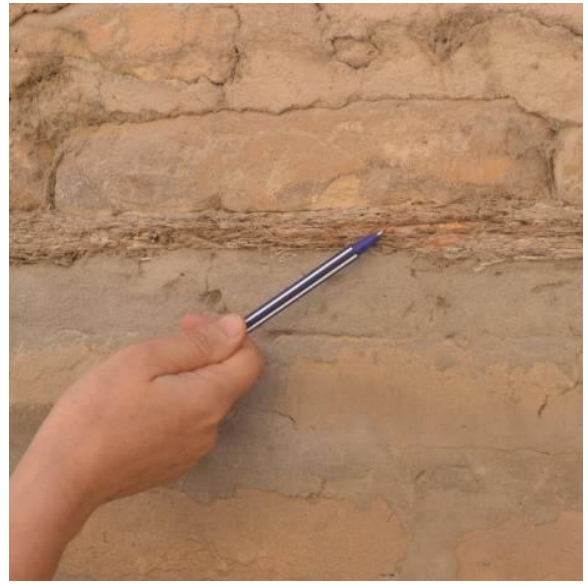

b)

Figure 5. The foundation of the "Tosh Hovli" (a) and the view of the reeds in Abdullah madrassah (b).

When analyzing the building materials and designs of many architectural monuments built in Khiva, ancient architects were well aware of the regularities of the impact of earthquakes on buildings. When the height of the foundation reached the surface, a series of brick was laid between the foundation and the clay in weak clay mortar.

This was also considered to be one of the most anti-seismic measures of ancient architects. The bricklayer, which is not connected to the lower and upper part of the building, allows the foundation to move under the dust, and the stresses on the foundation are not transmitted to the upper floors of the building. To quench the groundwater and earthquake force, the sand cushions were reinforced in the form of platforms, and the reeds were covered with cane beds.
The reeds are laid in the dusty part of the buildings. Before the surface of the coals, the mixture was spread evenly. A cane of $5-10 \mathrm{~cm}$ thick was pressed over the mixture. The reeds were spread over the reed layer and the bricks were covered. The soil beds are less resistant to forces that seek to move the foundation from the bottom of the building. The reed layer allows the rock and foundation to move slightly over the top of the building. This shift cut off the seismic forces without damaging the building's walls. When the shear layer is two, the shear stresses become more suppressed (Fig. 5 b).

Some of the architectural monuments in Khiva, which are $100-180 \mathrm{~cm}$ high, have been used horizontally as wooden beams of $25-35 \mathrm{~cm}$. size with various metal fastening elements (Figure 6). 


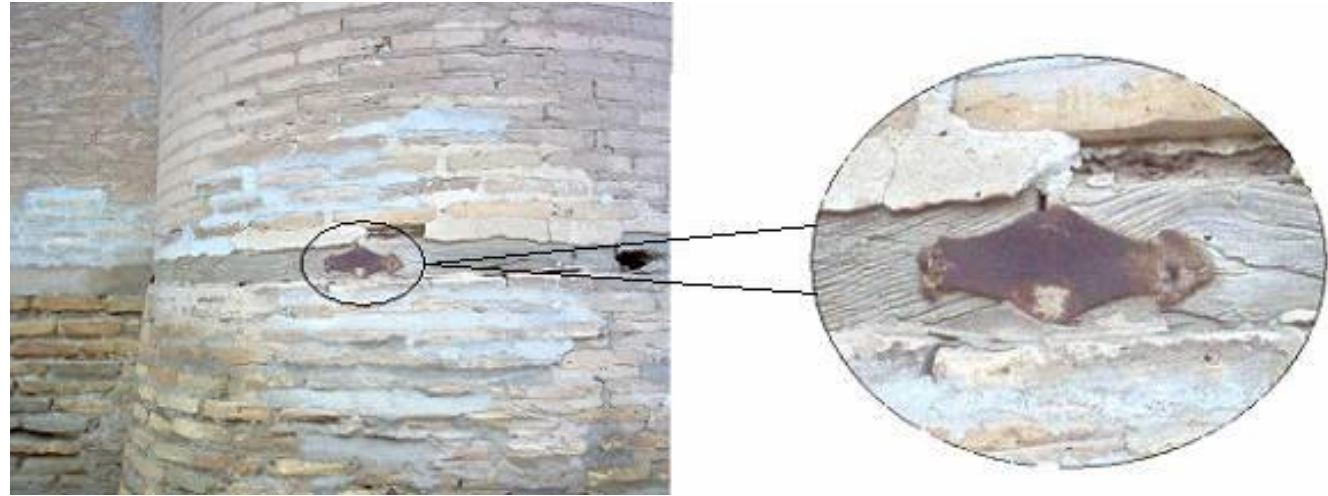

Figure 6. Anti -seismic wooden bars at the Qutlug Murad Inoq madrassah and fastening metal elements (Ichan Qala)

The main load-bearing structure of the Khiva architectural monuments is the brickwork. The exterior walls are usually thick, ranging from 1,5 meters to 5-6 meters. The role of building materials - bricks and plaster - is undoubtedly important in the strengthening of wall structures in Khiva's historical architectural monuments. Most of the medieval Khiva's historic architectural monuments have been restored by clay mortar. Ganch's biggest miracle is that over the years, its strength has increased over the time it was built (with the addition of various modifying additives). Gypsy mixtures are characterized by their fast melting. In the construction process, a gypsum mixture was used for the design of gates, domes and deck structures that needed this feature.

Flooring - the weight of the dome design is also provided through the exterior walls, which is why the buildings are made of quality bricks. Dome restoration techniques in the ancient architectural building of Khiva have been developed even before the Khorezmshakh period, that is, in the IX-X centuries. The roof designs of the Khiva architectural monuments are mostly made of baked bricks - with the dome of different shapes, with curved circular surfaces, skull-faced, chorsal, vertical and spherical domes (Fig. 7).
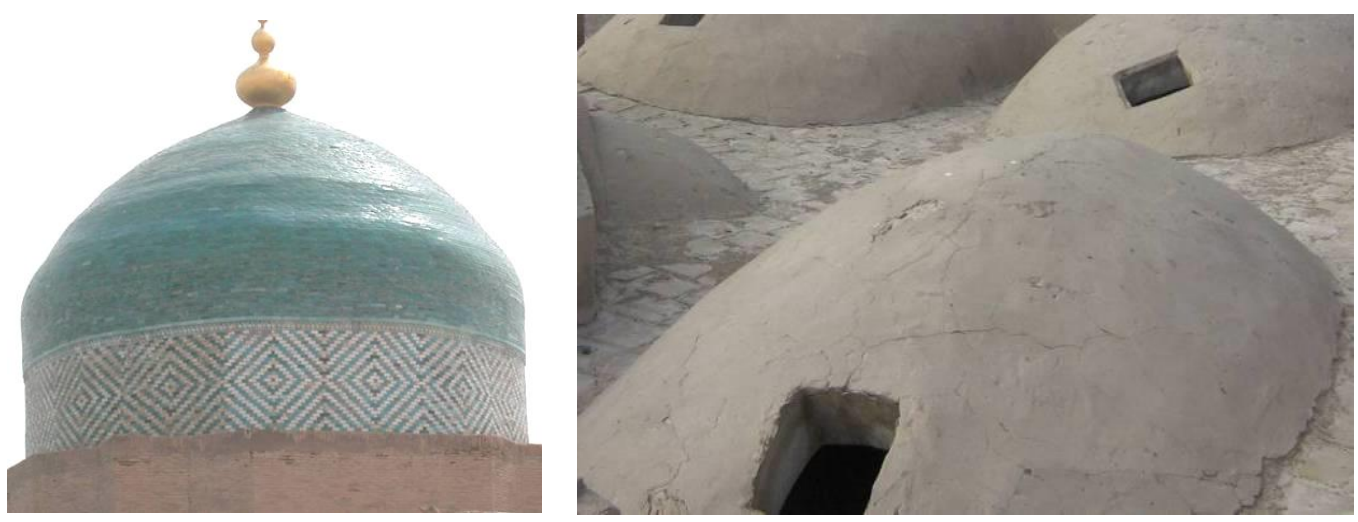

Figure 7. Spherical dome forms used for roofing the vertical dome and madrassas in the inner part of the Pahlavon Mahmud Complex 
The top of a large madrassah and buildings is often enclosed by a double dome. The interior is decorated modestly, there are specific shapes of the outer dome. The exterior dome is designed to protect the inner dome from exposure to atmospheric water, pollution, and cracking. The inner and outer domes are laid together.

It is difficult to analyze the openings in the Khiva architectural monuments separately and the domes' designs because they are interconnected structures by the nature of the work.
One of the most beautiful structures of ancient Khorezm architectural monuments is the gates. (Figure 8 ). During the analysis of the structures of each monument in Khiva, where the complex of historic architectural monuments is located, we found that each of the large and small domes was composed of several elemental openings or semi-arches. We also saw that the corridors were used in portraits of monuments, gateways and doorways, corridors, and even bridges.

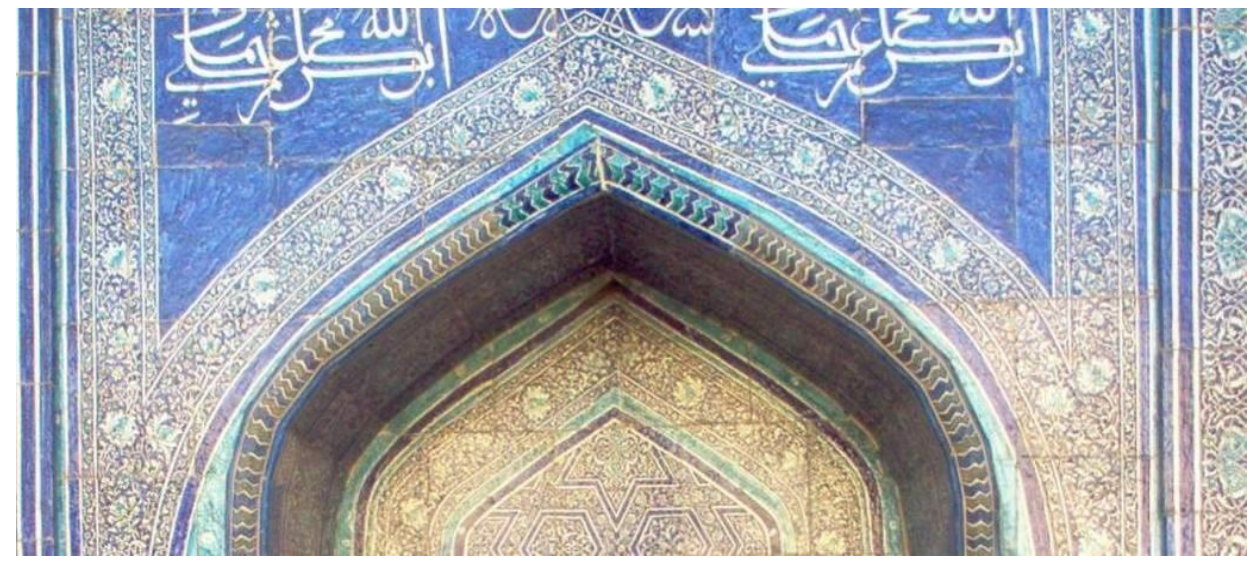

Figure 8. The floral design of the mihrab section of the "Kuhna Ark" mosque and its ornamentation.

The Minarets (tower) is a fully-brick brick structure with a circular cross-section with a brick staircase leading to a spiral staircase between the inner and outer circle walls. The strength of the tower depends on the strength of its design, the quality of the material and the depth of the foundation. The inner wall of the tower, as well as the outer wall, becomes thinner as it goes up. The foundations of heavy towers are 3 meters or deeper. For example, the foundation depth of the Saidniyaz
Shalikorboy minaret is 3.5 meters, and the foundation depth of the Islam Khoja minaret is 5.0 meters. Beneath the brick foundations, brick fractures were thrown, and brick platforms of various shapes and sizes were made on bedding. (Figure 9). It is a bedding layer that simultaneously functions as seismic insulation and waterproofing. Some of the monuments also have stone foundations (Qutlug Murad Inaq madrassah, Juma Masjid, etc.). 


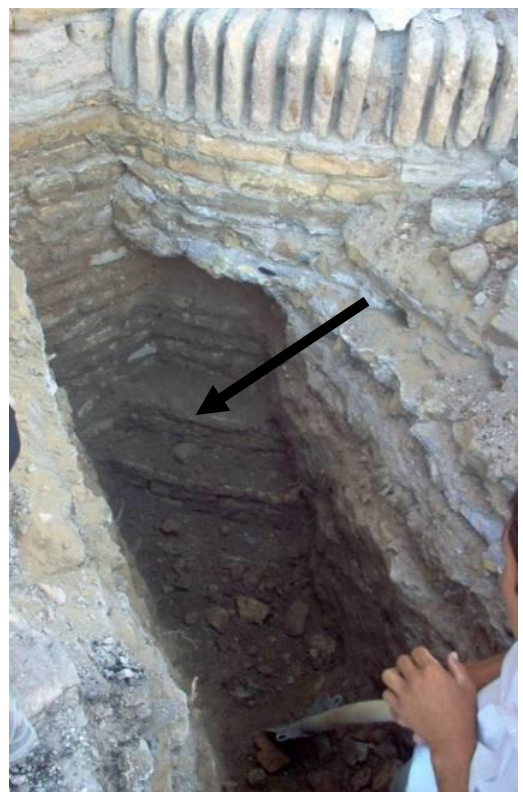

a)

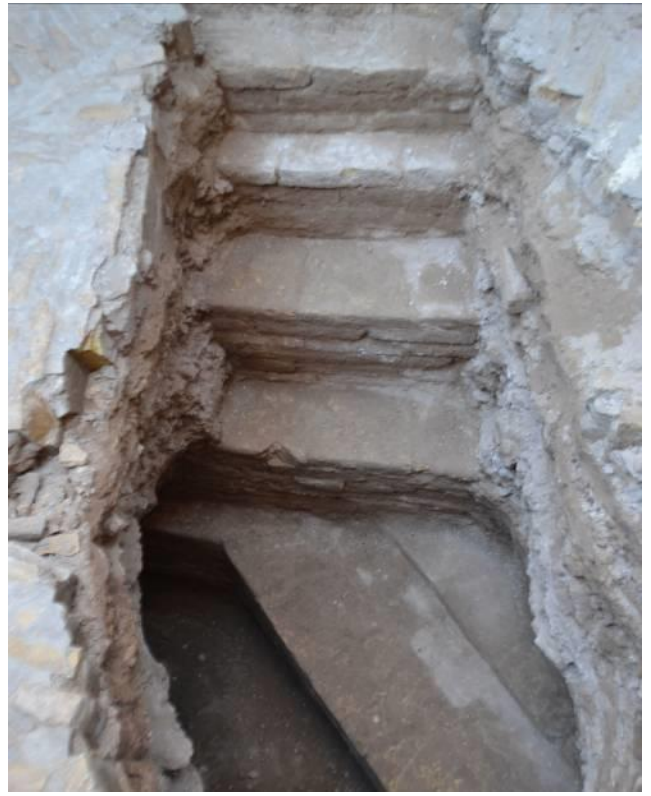

b)

Figure 9. (a) - Saidniyaz Shalikorboy minaret (2010)

(b) Overview of the foundations of the Islam Khoja minaret (2017)

According to the results it can be said that researching the work methods of the constructor-masters, who built beautiful and precious monuments of Khiva and who had perfect knowledge about this kind of construction, is now a vital issue. And also, we proved that architecture of Khorezm developed over the centuries and based on scientific laws.

\section{CONCLUSION}

The peculiarities of the construction of buildings and structures in the Khorezm oasis are that due to the lack of land in the oasis, the lack of green areas, the excess of heat from solar radiation in the summer, the construction legislation and building materials differ from other regions.

In short, each historical monument of ancient and modern Khiva is an individual structure, and their building materials and methods, as well as their structural structure do not duplicate each other.

\section{REFERENCES}

1. Azimov I. Khiva minoralari. 'Sanat'. 2002. № 7

2. Axmedov M.Q. O'rta Osiyo me`morchiligi tarixi. T.2015. 212 p.

3. Bulatova V.A., Notkin I.I. Xivaning arxitektura yodgorliklari. T.1963.48 p

4. Nazilov Dodo. Minora ramzi (Habits, rules and symbolic expressions). T.2006.123 p.

5. Khiva ming gumbaz shahri. Tashkent, 1997, 68 p. 88 p.

6. Zohidov P.SH. Xivinskie ugrozy. Stroitelstvo i arxitektura Uzbekistana. 1983. № 10. P 1725.

7. Qodirova T.F. Sanat, arxitektura va shaharsozlik tarixi. Oliy o`quv yurtlari uchun darslik. - Toshkent: 'cho'Ipon' NMIU. - 2012. - p. 4-97.

8. Mannoev S.B. O'zbekiston zamonaviy shaharsozligida me'moriy ansambl va komplekslar. Samarqand. 2014. Avtoreferat.

9. Mankovskaya L.Yu. Xiva. Muzey pod otkrytym nebom. T.1982. p 18. 
10. Masson M.E. Padayushiy minaret. (From the memoirs of a participant in the maintenance and rehabilitation of the "falling" northeastern minaret of the Ulugbek madrasah(1918-1932yy.). t.1969. p 67.

11. Durdieva G.S. Xivadagi 'Islomxo'ja' minorasining balandligini aniqlashdagi geodezik o'lchash ishlari. 'Problemy arxitektury I stroitelstva', Samarqand, 2011. № 2.

12. Notkin I.I. ansambl u vostochnyx vorot Ichan-Kaly v gorode Xive. Rukopis. 1957 y. arxiv Glav NPU obyektov kulturnovo naslediya.

13. Pribytkova A.M. konstruktivnie osobennosti sredneaziatskix minaretov X-XII cc. 'Arxitekturnoe naslediya'. M.1964. № 17.

14. Pugachenkova G.A. Arxitekturnie ruiny: restavratsiya ili konservatsiya. Stroitelstvo I arxitektura Uzbekistana. 1995. №1-2. P. 3739.

15. O'rolov A., Qodirova T.F. 'Orta Osiyo arxitektura yodgorliklarining tipologik asoslari'. T.2012. p 51. 